How to cite this article:

Ho, C. M., \& Lin, W. Y. (2020). Comparison of the pass-through speed models of different markets: An Empirical study of the markets of mainland China and Taiwan. International Journal of Banking and Finance, 15(1), 73-88. https://doi.org/10.32890/ijbf2020.15.1.9932

\title{
Comparison of the Pass-through Speed Models of Different Markets: An Empirical Study of the Markets of Mainland China and Taiwan
}

${ }^{1}$ Chi Ming Ho

${ }^{2} \mathrm{Wu}$ Yih Lin

Department of Finance,

Southern Taiwan University of Science and Technology

${ }^{1}$ Corresponding author: z0q@stust.edu.tw; hcmccu@gmail.com

2MA380204@stust.edu.tw

\section{A R T I C L E I N F O}

Article history:

Received 15 October 2019

Revised 9 January 2020

Accepted 15 January 2020

Published 31 March 2020

\section{Keywords:}

Bank competition, Boone Indicator, spread, pass-through speed Model, Error Correction Model.

JEL: G21, G28

\section{A B S T R A C T}

This paper adopted the Boone Indicator, developed by Boone et al. (2008) and Van Leuvensteijn et al. $(2011$; 2013), to investigate the influence of different pass-through spread models in the competition among banks in emerging markets. With the market share of banks as a dependent variable and marginal cost as an independent variable, this paper probed into the competition among banks regarding the loan market to determine whether competition on the loan interest rates of banks affected the pass-through of monetary policy-related interest rates. After analyzing approximately 5,657 entries of records of the banking industries in Taiwan and mainland China, this paper reached three significant conclusions: 1) the Boone Indicator Model pointed out that, competition in the banking market of mainland China 
was more intense than that of Taiwan; 2) empirical research based on the Interest Rate Spread Model indicated that the spread of mainland China was lower than that of Taiwan; 3) the Passthrough Speed Model implied that, the interest rate sensitivity of the market of mainland China was higher than that of the Taiwan market. The above results indicate that the influence of monetary policy pass-through on the interest rate of the market in mainland China is faster than in Taiwan.

\section{Introduction}

While many channels of monetary policies can shift policy effects to the economic system, the speed of the pass-through method plays the most vital role. The liberalization of the interest rate market will have a huge impact on the supervisory structure of commercial banks and social financing cost. Some evidence (Van Leuvensteijn, Bikker, Van Rixtel, \& Sorensen, 2011; Van Leuvensteijn, Sorensen, Bikker, \& Van Rixtel, 2013) suggests that, the costs of financial intermediaries are extremely high (Klein, 1971; Monti, 1972). As the banking system does not have strong competitiveness, all such factors weaken the monetary pass-through method. In fact, competition is the key to the success of monetary policies. In a competitive market, the changes in policy-related interest rates can be quickly transferred to the banking system, such as the provision of new interest rates to customers or interactive changes in the interest rates of banks and markets. The implementation of monetary policies requires a stable market pass-through speed mechanism to achieve the goal of economic stability of a government. Pass-through speed refers to the process of a government to adjust policy-based interest rates to change the interest rates of the monetary market. Banks transfer the cost of such changes to their retail interest rates. Most financial markets have forward-looking expectations, and even if the policyrelated interest rates of the government have not been changed, the retail interest rates of banks may have already reflected such changes.

Van Leuvensteijn et al. (2013) asserted that, despite new financial reforms conducted by emerging countries, competition in the banking industry have declined over the past decade. As stipulated by the interest rate system, traditional indicators fail to correctly assess competition in the banking market. 
Comparatively speaking, if the Boone Indicator Model was used to assess the banking business of mainland China, it would indicate that competition had increased (Van Leuvensteijn et al., 2013).

This paper explores the influence of the loan interest rates of banks on the competition of the loan market, and utilizes the pass-through mechanism, through which bank competition drives monetary policies. The model of Van Leuvensteijn et al. (2013), and the Error Correction Model (ECM) are applied to investigate the changes in interest rates of the two emerging economies of mainland China and Taiwan. Both China and Taiwan markets are regional financial centers in Asia, but there are still many comparable differences between the two in terms of financial supervision and economic policy. The Chinese market adopts a fixed exchange rate system. As it is a planned economy, policies on domestic economic stabilization are prioritized. As a result, capital transfer is slow and regulated and interest rate market is subject to limited uncertainties. However, the Taiwan market adopts a floating exchange rate. Therefore, fiscal and monetary policies would change rapidly according to international situations. As a result, capital transfer is fast. However, there are gaps in policy implementation, along with increase in uncertainties. Under the existing operations of two such emerging markets, how would the ultimate interest rate transmission change national income? There is no discussion on such a topic in the previous literature. In particular, the economic growth of China is critical to the prosperity of the global stock market, and therefore, it is a topic worth comparison and analysis. This model not only provides a consistent framework to compare the conclusions of the EU market, it also observes that, due to competition, market interest rates and bank interest rates are reflected in the monetary policies of central banks.

\section{Literature Review}

The earliest literature on bank competition is from the 1970s. The Monti-Klein Model of Klein (1971) and Monti (1972) assumed that the loan interest rates of banks had a certain degree of pricing power; lower demand elasticity led to higher intermediary profits (lower deposit interest rates led to higher loan interest rates) and weaker price competitiveness. Maudos and Fernandez de Guevara (2004) believed that the growth in the power of the banking market (i.e. the decrease in competitive pressure) resulted in the increase in net interest margins. In addition, Corvoisier and Gropp (2002) identified the difference between the retail interest rates of banks and interest rates of the monetary market. The retail loan interest rates of specific bank products rose sharply in concentrated markets. Leuvensteijn et al. (2013) analyzed the impact of loan interest rates of eight state-owned banks in the Eurozone on the competition of the loan market from 1994 to 2004. They employed their innovative approach, meaning the Boone Indicator, to assess the extent of the competition. Their empirical findings showed that, a competitive 
market hid significantly low interest rates. Policy-related interest rates would change bank interest rates and formed pass-through speed.

There were also findings in terms of the adjustment of loan interest rates via competition. Cottarelli and Kourelis (1994) and Borio and Fritz (1995) carried out cross-country analysis, and found that the monetary policy passthrough mechanism had significant effects in restraining competition. Thus, in an environment with weaker competition, banks often found loan interest rates fairly tricky, which was due to the barriers to entry. Mojon (2001) employed the index of deregulation, as established by Gual (1999), to test the influence of the competition of the banking industry on the pass-through of loan interest rates of banks in the Eurozone. Mojon found that, when the interest rates of the monetary market declined, higher competition tended to exert pressure on banks, in order to adjust loan interest rates faster. Scholnick (1996), Heinemann and Schu“ler (2002), Sander and Kleimeier (2002), and Kuan-Min and Thanh-Binh Nguyen (2010) found similar asymmetric pass-through effect. Additionally, De Bondt (2005) argued that the strong competition of other banks and the capital market could facilitate banks in the Eurozone to accelerate the adjustment of interest rates.

Many country-specific studies found the same results; when market competition was weak, the entry of market interest rates into the pass-through mechanism of banks would also turn weak (Heffernan,1997). De Graeve et al. (2007) estimated the decisive factors of the pass-through speed behavior of Belgian banks, and discovered that banks with stronger market power adopted less competitive pricing policies. Lago-Gonza'lez and Salas-Fuma's (2005) conducted microeconomic analysis of Spanish banks, and their evidence suggested that the combination of the price cost adjustment market power of banks led to price rigidity and asymmetric pass-through. Bredin and O'Reilly (2004) also showed similar results. Kok Sørensen and Werner (2006) deemed that, pass-through and bank competition in different countries in the Eurozone were different. Moreover, Gropp, Kok Sørensen, and Lichtenberger (2007) focused on the Eurozone, and held that the effect of pass-through provided positive impact on the level of competition in the banking sector.

Van Leuvensteijn et al. (2013) employed new competition indicators, which were unlike previous measurement methods (Boone, 2008; Bikker \& van Leuvensteijn, 2008; van Leuvensteijn et al., 2011). They argued that, in a highly competitive market, more efficient companies were likely to have greater market share. The basic idea of the Boone Indicator is market power hypothesis, that is, efficiency hypothesis. In a highly competitive market, more efficient companies are likely to have a greater market share. In other words, it assumes that market share, through marginal cost, determines if a bank is competitive in a competitive market. Therefore, this paper further examines how an efficient market changes over time, how the changes in competition affect the loan costs of families and enterprises, and how policy-related interest rates are 
passed through to the loan interest rates of banks. This paper intends to prove the following three hypotheses: 1) More competitive markets have smaller Boone Indicators; 2) In a highly competitive market, the spread is low; and 3) In a highly competitive market, short-term bank interest rates are more sensitive than market interest rates.

\section{Data and Model}

\subsection{Data Sources and Description}

The variable data used in the model of this paper were from the unbalance panel data of the Taiwan Economic Journal (TEJ). The samples consisted of quarterly data from 2005 to 2016, and contained a total of 1,553 entries of records from 33 public banks. In addition to the TEJ, the data of mainland China came from the CSMAR Solution Journal. These samples were also from 2005 to 2016, and contained a total of 3,840 entries of the observed values of 96 banks, excluding missing values.

The Boone Indictor was used to assess market competition, as well as the correlation between market share and marginal cost. The market share in this paper was the result of the sum of the quarterly loans of each bank for each year divided by the sum of the quarterly loans of an individual bank each year. Marginal cost refers to the average cost and income ratio, as proposed by Van Leuvensteijn et al. (2011). The data of bank interest rates were the monthly average loan interest rates of the banks of Taiwan and mainland China. In order to obtain sensitivity, market interest rates were the monthly average weighted overnight lending interest rates. A total of 264 entries of quarterly data from 2005 and 2016 in the markets of mainland China and Taiwan were observed.

\subsection{Model Development and Research Hypotheses}

\subsubsection{Boone Indicator Model}

$$
\begin{aligned}
& \ln \left(m s_{i, t}\right)=\alpha+\beta_{t} \ln \left(m c_{i, t}\right)+\sum_{t=1, \ldots . .,(T-1)} \gamma_{t} d_{t}+\varepsilon_{i, t} \\
& \ln \left(m s_{i, t}\right)=\alpha+\beta_{t} \ln \left(m c_{i, t}\right)+f D+g D \ln \left(m c_{i, t}\right)+\varepsilon_{i, t}
\end{aligned}
$$

I: country. t: time. ms: market share of each bank. mc: marginal cost of each bank. $\varepsilon$ : residuals. $\beta$ : Boone Indicator. $(\alpha, \beta, \gamma, \mathrm{f}, \mathrm{g})$ : parameters. d: virtual variable. ( $-\beta \mathrm{t})$ means the negative parameter of $\beta \mathrm{t}$, indicating efficient market share. Hence, Eq. (3.1a) is rewritten as Eq. (3.1b) to describe the Boone Indicator of $\beta$ t. Theoretically, the Taiwanese market is more competitive than that of mainland China, as the loan interest rates of Taiwan during the research period 
were lower than those of mainland China. The first hypothesis is proposed:

$\mathrm{H}_{10}: \beta_{\mathrm{t}}(T)-\beta_{\mathrm{t}}(\mathrm{C})<0 ; \mathrm{H}_{11}: \beta_{\mathrm{t}}(\mathrm{T})-\beta_{\mathrm{t}}(\mathrm{C}) \geq 0 . \beta \mathrm{t}(\mathrm{T})$ and $\beta \mathrm{t}(\mathrm{C})$ represent the Boone Indicators of Taiwan and mainland China.

\subsubsection{Interest Rate Spread Model}

If there is a co-integration relationship between bank interest rates and their corresponding market prices, ECM will be the most suitable model. This paper considers the interest rates of two products of relevant banks, and develops the following two model equations.

$$
\begin{aligned}
& \mathrm{BR}_{\mathrm{i}, \mathrm{t}}=\zeta \mathrm{BI}_{\mathrm{i}, \mathrm{t}}+\eta_{\mathrm{i}} \mathrm{MR}_{\mathrm{i}, \mathrm{t}}+\theta \mathrm{BI}_{\mathrm{i}, \mathrm{t}} \mathrm{MR}_{\mathrm{i}, \mathrm{t}}+\mathrm{k}_{\mathrm{i}} \mathrm{D}_{\mathrm{i}}+\mu_{\mathrm{i}, \mathrm{t}} \\
& \Delta \mathrm{BR}_{\mathrm{i}, \mathrm{t}}=\lambda_{\mathrm{i}} \mu_{\mathrm{i}, \mathrm{t}-1}+\mu_{\mathrm{i}} \Delta \mathrm{MR}_{\mathrm{i}, \mathrm{t}}+\xi \mathrm{BI}_{\mathrm{i}, \mathrm{t}} \Delta \mathrm{MR}_{\mathrm{i}, \mathrm{t}}+\mathrm{v}_{\mathrm{i}, \mathrm{t}} \\
& \mathrm{BR}_{\mathrm{i}, \mathrm{t}}=\mathrm{c}+\mathrm{hBI}_{\mathrm{i}, \mathrm{t}} \mathrm{MR}_{\mathrm{i}, \mathrm{t}}+\mathrm{jD}_{\mathrm{i}}+\mathrm{mDBI}_{\mathrm{i}, \mathrm{t}} \mathrm{MR}_{\mathrm{i}, \mathrm{t}}+\mu_{\mathrm{i}, \mathrm{t}}
\end{aligned}
$$

i means country $(i=1, \ldots, N)$. T means month $(t=1, \ldots, T)$. Model $(3.2 \mathrm{a})$ reflects the long-term equilibrium pass-through. Model (3.2b) indicates the long-term equilibrium and short-term adjustment via bank interest rates. This study first discusses the long-term influence of Model (3.2a), as the short-term influence of Model (3.2b) is determined by the error of $\mu_{\mathrm{i}, \mathrm{t}}$ of Model (3.2a). $\mathrm{BR}$ means bank interest rates (loan interest rates). $\Delta \mathrm{BR}$ refers to the monthly changes in bank interest rates. BIi, t stands for country (i) and time (t) of the Boone Indicator. The market price of each country $\left(\eta_{i} M_{i, t}=\right.$ long-term changes in interest rates, and $\mu_{\mathrm{i}} \Delta \mathrm{MR}_{\mathrm{i}, \mathrm{t}}=$ short-term changes in market interest rates).

Market interest rates $\left(\mathrm{MR}_{\mathrm{i}, \mathrm{t}}\right)$ multiply the Boone Indicator (BI). $\left(\theta \mathrm{BI}_{\mathrm{i}, \mathrm{t}} \mathrm{MR}_{\mathrm{i}, \mathrm{t}}=\right.$ Boone long-term changes in market interest rates and $\xi \mathrm{B}_{\mathrm{i}, \mathrm{t}} \Delta \mathrm{MR}_{\mathrm{i}, \mathrm{t}}=$ short-term changes in Boone Indicator). Country virtual variable (Di). The shortterm model of Model (3.2b) includes error correction item $\left(\lambda_{\mathrm{i}} \mu_{\mathrm{i}, \mathrm{t}-1}\right)$.

In Models (3.2a) and (3.2b) and various competitive effects [parameters of $((\zeta, \xi, \theta)$ (panel)], Eq. 3.3 can be deduced by Eq. 3.2a. The pass-through effect of Interest Rate Spread Model Eq. (3.2a) may be direct and complete. We assume $\eta_{\mathrm{i}}=1 ; \theta=0$ to obtain Interest Rate Spread Model Eq. (3.3).

$$
\left(\mathrm{BR}_{\mathrm{i}, \mathrm{t}}-\mathrm{MR}_{\mathrm{i}, \mathrm{t}}\right)=\mathrm{C}+\delta \mathrm{BI}_{\mathrm{i}, \mathrm{t}}+\mathrm{K}_{\mathrm{i}} \mathrm{D}_{\mathrm{i}}+\zeta \mathrm{D}_{\mathrm{i}} * \mathrm{BI}_{\mathrm{i}, \mathrm{t}}+\mu_{\mathrm{i}, \mathrm{t}}
$$

The Spread Model is adopted. Hypothesis 2: In a highly competitive market, the spread (bank interest rates - market interest rates) is low. Theoretically, the competitive spread of Taiwan is smaller than that of mainland China, as the loan interest rates of Taiwan during the research period were lower than those of mainland China. See Hypothesis 2, as follows: 
$\mathrm{H}_{20}: \zeta(T)-\zeta(C)>0 ; \quad \mathrm{H}_{21}: \zeta(T)-\zeta(C) \leq 0 . \zeta(\mathrm{T})$ and $\zeta(\mathrm{C})$ means the spreads of Taiwan and mainland China.

\subsubsection{Pass-Through Speed Model}

In order to verify the speed equation, this paper rewrites Eq. (3.2b) into Eq. (3.2c); and mDBI_(i,t) MR_(i,t), virtual variable (D), Boone Indicator(BI), and market interest rates (MR) are multiplied together to obtain coefficient $\mathrm{m}$, in order to determine when the competition of Taiwan is greater than mainland China; if the pass-through speed is faster, while the $\mathrm{p}$ value of coefficient $\mathrm{m}$ is significant. Hypothesis 3 : In a highly competitive market, short-term bank interest rates are more sensitive than market interest rates. See Hypothesis 3, as follows: $\mathrm{H}_{30}: \xi(T)-\xi(\mathrm{C})>0 ; \quad \mathrm{H}_{31}: \xi(T)-\xi(\mathrm{C}) \leq 0 . \xi(\mathrm{T})$ and $\xi(\mathrm{C})$ represent the pass-through speeds of Taiwan and mainland China, respectively.

\section{Analysis of Empirical Results}

\subsection{Descriptive Analysis}

Table 1 shows the descriptive statistics of all samples of Taiwan, including bank interest rates (BR), market interest rates (MR), Boone indicator (BI), BI*MR, BR-MR, market share (MS), and marginal cost (MC). Table 2 displays the descriptive statistics of all samples of mainland China, including mean, standard deviation, median, maximum, and minimum. Based on the observations of Tables 1 and 2, the Boone coefficient of Taiwan was higher, indicating that it was less competitive, while that of mainland China was lower, indicating that it was more competitive.

Table 1. Descriptive Statistics of Sample from Taiwan

\begin{tabular}{cccccccc}
\hline $\begin{array}{c}\text { Taiwan } \\
\text { market }\end{array}$ & $\begin{array}{c}\text { Bank } \\
\text { Interest } \\
\text { Rates }\end{array}$ & $\begin{array}{c}\text { Market } \\
\text { Interest } \\
\text { Rates }\end{array}$ & $\begin{array}{c}\text { Boone } \\
\text { Indicator }\end{array}$ & BI*MR & Spread & $\begin{array}{c}\text { Market } \\
\text { Share }\end{array}$ & $\begin{array}{c}\text { Marginal } \\
\text { Cost }\end{array}$ \\
\hline $\begin{array}{c}\text { Mean } \\
\text { Standard }\end{array}$ & 3.2686 & 0.8138 & 0.1112 & 2.8986 & 2.4547 & 0.0436 & 0.4342 \\
Deviation & 0.6316 & 0.7040 & 4.8837 & 5.7725 & 0.1974 & 0.0339 & 0.1270 \\
Median & 2.8830 & 0.3880 & -2.1324 & -0.5852 & 2.4565 & 0.0269 & 0.4237 \\
Maximum & 4.4430 & 2.4960 & 9.2208 & 18.4704 & 3.6770 & 0.1377 & 0.7819 \\
Minimum & 2.5630 & 0.0970 & -6.5300 & -2.2572 & 1.5600 & 0.0041 & 0.1950 \\
\hline
\end{tabular}


Table 2. Descriptive Statistics of Sample from Mainland China

\begin{tabular}{cccccccc}
\hline $\begin{array}{c}\text { Mainland } \\
\text { China } \\
\text { market }\end{array}$ & $\begin{array}{c}\text { Bank } \\
\text { Interest } \\
\text { Rates }\end{array}$ & $\begin{array}{c}\text { Market } \\
\text { Interest } \\
\text { Rates }\end{array}$ & $\begin{array}{c}\text { Boone } \\
\text { Indicator }\end{array}$ & BI*MR & Spread & $\begin{array}{c}\text { Market } \\
\text { Share }\end{array}$ & $\begin{array}{c}\text { Marginal } \\
\text { Cost }\end{array}$ \\
\hline $\begin{array}{c}\text { Mean } \\
\text { Standard }\end{array}$ & 5.8418 & 2.7550 & -2.4491 & -11.2121 & 3.0867 & 0.0272 & 0.4928 \\
Deviation & 0.4865 & 1.2102 & 4.2567 & 15.8631 & 1.1326 & 0.0430 & 0.1547 \\
Median & 6.0000 & 2.7700 & -3.9605 & -10.4027 & 3.0072 & 0.0108 & 0.4581 \\
Maximum & 7.2900 & 5.6036 & 3.7828 & 6.7369 & 4.8172 & 0.1872 & 0.9710 \\
Minimum & 4.3500 & 1.0600 & -9.7 & -54.3552 & 0.3963 & 0.0001 & 0.2163 \\
\hline
\end{tabular}

\subsection{Heterogeneous Variation Robustness Test}

In order to avoid model distortion when descriptive analysis, correlation coefficient, covariance, and variables are extremely similar, this study added the Newey-west Test, which could exclude self-correlation and heterogeneous variation to reach the best unbiased estimator. The first step included heterogeneous variation test BP (Breusch) and the white test. Table 3 shows that all three equations reject the null hypothesis (H0) of homogeneity and variation, implying that all three models have heterogeneous variations.

Table 3. Test of Heterogeneous Variations of Three Models

\begin{tabular}{|c|c|c|c|c|c|c|c|c|c|}
\hline $\begin{array}{l}\text { Boone } \\
\text { Model }\end{array}$ & & & & $\begin{array}{l}\text { Speed } \\
\text { Model }\end{array}$ & & & $\begin{array}{l}\text { Interest } \\
\text { Rate } \\
\text { Spread } \\
\text { Model }\end{array}$ & & \\
\hline $\begin{array}{l}\text { BP } \\
\text { test }\end{array}$ & & & & $\mathrm{BP}$ test & & & $\mathrm{BP}$ test & & \\
\hline $\begin{array}{l}\text { F } \\
\text { statistics }\end{array}$ & 22.6074 & P value & 0 & 1362.569 & $P$ value & 0 & 283.075 & $\mathrm{P}$ value & 0 \\
\hline $\begin{array}{l}\text { LM } \\
\text { statistics }\end{array}$ & 67.0279 & P value $X(3)$ & 0 & 241.1677 & $P$ value $X(2)$ & 0 & 181.355 & $\mathrm{P}$ value $\mathrm{X}(2)$ & 0 \\
\hline White test & & & & White test & & & White test & & \\
\hline $\begin{array}{l}\text { F } \\
\text { statistics }\end{array}$ & 24.1204 & $P$ value & 0 & 7.275 & $P$ value & 0 & 20.201 & $\mathrm{P}$ value & 0 \\
\hline $\begin{array}{l}\text { LM } \\
\text { statistics }\end{array}$ & 118.0894 & $P$ value $X(5)$ & 0 & 32.6216 & $P$ value $X(5)$ & 0 & 74.276 & $P$ value $X(5)$ & 0 \\
\hline
\end{tabular}




\subsection{Results of Regression Analysis}

\subsubsection{Boone Model of Taiwan and Mainland China}

In a competitive market, the Boone Indicator, meaning the marginal cost coefficient, is negative, as shown by $\mathrm{g}$ in Eq. (3.1b). This paper supposes that, if Taiwan entered a developing country earlier than mainland China, the loan interest rates of Taiwan during the research period would be lower than those of mainland China. Hence, the Taiwanese market should be more competitive. However, the test results (Table 4) of this paper rejects H0. The results show that mainland China is more competitive than Taiwan in terms of the loan market. Therefore, H10 is rejected, implying that lower intermediary profits lead to stronger price competitiveness, which is similar to Klein (1971).

Table 4. Regression Analysis Results of Boone Model

\begin{tabular}{lcccc}
\hline \multicolumn{5}{c}{ Dependent Variable: Market Share (General Regression) } \\
\hline \multicolumn{1}{c}{$\begin{array}{c}\text { Independent } \\
\text { Variable }\end{array}$} & $\begin{array}{c}\text { Correlation } \\
\text { Coefficient }\end{array}$ & $\begin{array}{c}\text { Standard } \\
\text { Deviation }\end{array}$ & T Statistics & P Value \\
\hline $\begin{array}{l}\text { Intercept } \\
\text { Marginal cost }\end{array}$ & 0.004083 & 0.000789 & 5.171947 & 0.0001 \\
$\begin{array}{l}\text { Dummy variable } \\
\text { Dummy variable }\end{array}$ & 0.021126 & 0.002092 & 10.0994 & 0.0005 \\
$\begin{array}{l}\text { multiplies } \\
\text { marginal cost }\end{array}$ & 0.039935 & 0.0068968 & 0.428676 & 0.6682 \\
\hline R-squared & & 0.1218 & 0.006 \\
\hline
\end{tabular}

In order to prevent model distortion, this paper also tested the Neweywest Model, as shown in Table 5. The results also rejected H0, that Taiwan is more competitive than mainland China. As mainland China is more competitive than Taiwan, thus, $\mathrm{H}_{10}$ is also rejected. 
Table 5. Results of Newey-west Regression of Boone Model

\begin{tabular}{lcccc}
\hline \multicolumn{5}{c}{ Dependent Variable: Market Share (Newey-west) } \\
\hline $\begin{array}{c}\text { Independent } \\
\text { Variable }\end{array}$ & $\begin{array}{c}\text { Correlation } \\
\text { Coefficient }\end{array}$ & $\begin{array}{c}\text { Standard } \\
\text { Deviation }\end{array}$ & T Statistics & P Value \\
\hline Intercept & 0.004083 & 0.001538 & 2.654738 & 0.008 \\
Marginal Cost & 0.021126 & 0.004543 & 4.649663 & 0.0005 \\
$\begin{array}{l}\text { Dummy variable } \\
\text { Dummy variable }\end{array}$ & 0.001285 & 0.004219 & 0.304538 & 0.7607 \\
$\begin{array}{l}\text { multiplies } \\
\text { marginal cost }\end{array}$ & 0.039935 & 0.010863 & 3.676347 & 0.0002 \\
\hline \begin{tabular}{l} 
R-squared \\
\hline
\end{tabular} & 0.1218 & & \\
\hline
\end{tabular}

\subsubsection{Interest Rate Spread Models of Taiwan and Mainland China}

Table 6 demonstrates the general regression of the Speed Model. The Boone Indicator points out that, in a more competitive market, the pass-through between the loan interest rates of banks and market interest rates is faster. The Virtual variable, the Boone Indicator, and market interest rates are multiplied together. Coefficient $\mathrm{m}$ in Eq. (3.2c) is used. This paper supposes that, if Taiwan entered a developing country earlier than mainland China, the loan interest rates of Taiwan during the research period would be lower than those of mainland China. Hence, Taiwan should be more competitive than mainland China; and the pass-through speed of the former should be faster than the latter. The results show that, a more competitive loan market has more complete pass-through speed. The pass-through speed of mainland China is faster than that of Taiwan. Thus, $\mathrm{H}_{20}$ is rejected.

Table 6. Regression Analysis Results of the Speed Model

\begin{tabular}{ccccc}
\hline \multicolumn{4}{c}{ Dependent Variable: Bank Interest Rates (General Regression) } \\
\hline $\begin{array}{c}\text { Independent } \\
\text { Variable }\end{array}$ & $\begin{array}{c}\text { Correlation } \\
\text { Coefficient }\end{array}$ & $\begin{array}{c}\text { Standard } \\
\text { Deviation }\end{array}$ & T Statistics & P Value \\
\hline Intercept & 5.812833 & 0.058696 & 99.03251 & 0.0007 \\
\hline
\end{tabular}


Dependent Variable: Bank Interest Rates (General Regression)

\begin{tabular}{lcccc}
\hline \multicolumn{1}{c}{$\begin{array}{c}\text { Independent } \\
\text { Variable }\end{array}$} & $\begin{array}{c}\text { Correlation } \\
\text { Coefficient }\end{array}$ & $\begin{array}{c}\text { Standard } \\
\text { Deviation }\end{array}$ & T Statistics & P Value \\
\hline $\begin{array}{l}\text { Boone Indicator } \\
\text { multiplies market } \\
\text { interest rates }\end{array}$ & -0.017685 & 0.004437 & -3.986113 & 0.0002 \\
$\begin{array}{l}\text { Dummy variable } \\
\text { Dummy variable, }\end{array}$ & -2.799504 & 0.079158 & -35.3659 & 0.0005 \\
$\begin{array}{l}\text { Boone Indicator, } \\
\text { and market } \\
\text { interest rates } \\
\text { multiply together }\end{array}$ & 0.105759 & 0.009365 & 11.29316 & 0.002 \\
\hline R-squared & & & & \\
\hline
\end{tabular}

Table 7 shows the Speed Model Newey-west adjustment, and indicates that a more competitive loan market has more complete pass-through speed. The passthrough speed of mainland China is faster than that of Taiwan, thus, $\mathrm{H}_{20}$ is also rejected.

Table 7. Newey-west Regression Analysis Results of the Speed Model

Dependent Variable: Bank Interest Rates (Newey-west)

\begin{tabular}{lcccc}
\hline \multicolumn{1}{c}{$\begin{array}{c}\text { Independent } \\
\text { Variable }\end{array}$} & $\begin{array}{c}\text { Correlation } \\
\text { Coefficient }\end{array}$ & $\begin{array}{c}\text { Standard } \\
\text { Deviation }\end{array}$ & T Statistics & P Value \\
\hline $\begin{array}{l}\text { Intercept item } \\
\text { 5oone Indicator } \\
\text { multiplies market }\end{array}$ & -0.812833 & 0.140954 & 41.2393 & 0.0007 \\
$\begin{array}{l}\text { interest rates } \\
\begin{array}{l}\text { Virtual variable } \\
\text { Virtual variable, }\end{array}\end{array}$ & -2.799504 & 0.156414 & -17.89808 & 0.0005 \\
$\begin{array}{l}\text { Boone Indicator, } \\
\text { and market } \\
\text { interest rates } \\
\text { multiply together }\end{array}$ & 0.105759 & 0.010366 & 10.20277 & 0.0273 \\
\hline \begin{tabular}{l} 
R-squared \\
\hline
\end{tabular} & & & & 0.002 \\
\hline
\end{tabular}




\subsubsection{Interest Rate Indicator Pass-through Models of Taiwan and Mainland China}

The Boone Indicator refers to the spread of loan interest rates of banks minus the market interest rates in a competitive market. The Boone Indicator multiplies virtual variables to reach a positive coefficient, such as the $\zeta$ value in Eq. (3.3). This paper supposes that if Taiwan entered a developing country earlier than mainland China, the loan interest rates of Taiwan during the research period would be lower than those of mainland China. Hence, the spread of Taiwan should be smaller than that of mainland China; however, Table 8 shows that the spread (loan interest rates of banks minus market interest rates in the loan market) of mainland China is smaller than that of Taiwan, thus, H30 is rejected.

Table 8. Regression Analysis Results of the Spread Model

\begin{tabular}{lcccc}
\hline \multicolumn{4}{c}{ Dependent Variable: Loan Interest Rates of Banks Minus Market Interest Rates } \\
(General Regression)
\end{tabular}

In order to prevent model distortion, Newey-west regression is tested. Table 9 shows the test of the Spread Model. The results reject the null hypothesis that Taiwan is more competitive than mainland China, and that the former's spread is smaller than that of the latter. The market in mainland China is more competitive than Taiwan, thus, the former's spread is smaller than that of the latter, and therefore $\mathrm{H}_{30}$ is rejected. 
Study of the Markets of Mainland China and Taiwan: 73-88

Table 9. Newey-West Regression Analysis Results of the Spread Model

\begin{tabular}{lcccc}
\hline \multicolumn{5}{c}{ Dependent Variable: Loan Interest Rates of Banks Minus Market Interest Rates } \\
(Newey-west)
\end{tabular}

\subsection{Empirical Results}

Based on the robustness analysis, this paper reached the following conclusions. Eq. (3.1b) in the Boone Model of Hypothesis 1 assumes that Taiwan is more competitive than mainland China. However, the results showed the opposite. Eq. (3.3) in the Spread Model of Hypothesis 2 assumes that the spread of the loan market of Taiwan is smaller than that of mainland China. However, the result indicated the opposite. Eq. (3.2c) in the Speed Model of Hypothesis 3 assumes that the pass-through speed of Taiwan is faster than that of mainland China. However, the result revealed the opposite.

\section{Conclusion and Suggestion}

China's loan market is more competitive which implies a lower spread; in other words, competition may lower interest rates. However, bank competition may lead to more dangerous behavior, resulting in financial turmoil. There is no recent literature that explored in depth the correlation between bank competition and interest rates in emerging markets. Some literature adopted the Lerner indicator, a traditional indicator and Panzar-Rosse H statistics or HHI concentration, which are limited by the regulations of the interest rate system, and thus, fail to effectively assess bank competition. Van Leuvensteijn et al. (2013) assessed the competition among banks in China, and deemed that the Boone Indicator was the best way to assess such competition. However, the Boone Indicator is a relatively 
immature tool, and is not supported by literature. Therefore, this paper adopted the Boone Indicator to compare bank competition in the markets of mainland China and Taiwan, and reached three important empirical conclusions, which can be compared with Leuvensteijn, Bikker, Adrian, Rixtel and Sorensen (2013), Cottarelli and Kourelis (1994), and Borio and Fritz (1995). During the research period, the loan interest rates of Taiwan were lower than those of mainland China; however, the deregulation of Taiwan was earlier than that of mainland China. Theoretically, the loan market of Taiwan should be more competitive than that of mainland China. However, the empirical results indicated that, the competition among banks in the loan market of mainland China is more intense than that of Taiwan. In addition, China has smaller spread and faster pass-through speed than Taiwan, which is consistent with Klein (1971). The results of this paper could serve as complementary reference for literature on the Boone Indicator.

Overall, after comparing the empirical analysis results with the MundellFlemming model, we can see that China adopts a fixed exchange rate system featuring high interest rate sensitivity, fast regulation and small implicit LM slope. When the People's Bank of China adopts an expansionary monetary policy, global imbalances would be adjusted through foreign exchange reserves, without impacting on long-term balanced national income. In contrast, the Taiwan market features low interest rate sensitivity and slow regulation. As the Taiwan market adopts a floating exchange rate, global imbalances as a result of expansionary monetary policy would be improved through devaluation, leading to significant increase in long-term balanced GDP. Even so, based on policy dynamics of the Mundell-Flemming model, national income growth is possible for both Mainland China and the Taiwan market, if fiscal policy is followed.

\section{References}

Bikker, J. A., \& van Leuvensteijn, M. (2008). Competition and efficiency in the Dutch life insurance industry. Applied Economics, 40, 2063-84. d o i . org/10.1080/00036840600949298

Boone, J. (2008). A new way to measure competition. The Economic Journal, 118, 1245-1261. doi.org/10.1111/j.1468-0297.2008.02168.x |

Borio, C., \& Fritz, W. (1995). The response of short-term bank lending rates to policy rates: A cross-country perspective. BIS Working Paper No. 27.

Bredin, D., \& O'Reilly, G. (2004). An analysis of the transmission mechanism of monetary policy in Ireland. Applied Economics, 36, 49-58. d o i abs/10.1080/0003684042000177198

Cottarelli, C., Ferri, G., \& Generale, A. (1995). Bank lending rates and financial structure in Italy: A case study. IMF Working Paper No. 38.

Cottarelli, C., \& Kourelis, A. (1994). Financial structure, bank lending rates and the transmission of monetary policy. IMF Staff Paper, 42, 670-700. 
Study of the Markets of Mainland China and Taiwan: 73-88

De Bondt, G. J. (2005). Interest rate pass-through: Empirical results for the euro area. German Economic Review, 6, 37-78. doi.org/10.1111/j.14656485.2005.00121.x

De Graeve, F., De Jonghe, O., \& Vander Vennet, R. (2007). Competition, transmission and bank pricing policies: Evidence from Belgian loan and deposit markets. Journal of Banking and Finance, 31, 259-78.

Gual, J. (1999). Deregulation, integration and market structure in European banking. Journal of the Japanese and International Economies, 13, 372-96. doi.org/10.1006/jjie.1999.0428

Gropp, R., Kok Sørensen, C., \& Lichtenberger, J. (2007). The dynamics of bank spreads and financial structure. European Central Bank Working Paper Series No. 714.

Heinemann, F., \& Schu“ ler, M. (2002). Integration benefits on EU retail credit markets - evidence from interest rate pass-through, mimeo $\mathrm{ZEW}$.

Heffernan, S. A. (1997). Modelling British interest rate adjustment: An errorcorrection approach. Economica, 64, 211-31.

Kuan-Min, W., \& Thanh-Binh Nguyen, T. (2010). Asymmetric passthrough and risk of interest rates: An empirical exploration of Taiwan and Hong Kong. Applied Economics, 42, 659-70. DOI: 10.1080/00036840701704444

Kok Sørensen, C., \& Werner, T. (2006). Bank interest rate pass-through in the euro area: A cross-country comparison. ECB Working Paper Series No. 580.

Klein, M. (1971). A theory of the banking firm. Journal of Money, Credit, and Banking, 3, 205-18.

Lago-Gonza' lez, R., \& Salas-Fuma' s, V. (2005). Market power and bank interest rate adjustments. Banco de Espan $\sim$ a Working Paper No. 0539.

Maudos, J., \& Fernández de Guevara, J. (2004). Factors explaining the interest margin in the banking sectors of the European Union. Journal of Banking \& Finance, 28(9), 2259-2281.doi.org/10.1016/j.jbankfin.2003.09.004

Mojon, B. (2001), Financial structure and the interest rate channel of ECB monetary policy. Economie et Provision, 147, 89-115.

Monti, M. (1972). Deposit, credit, and interest rate determination under alternative bank objectives, In G. P. Sezgo \& K. Shell (Eds.), Mathematical methods in investment and finance. Amesterdam: North Holland.

Scholnick, B. (1996). Asymmetric adjustment of commercial bank interest rates: Evidence from Malaysia and Singapore. Journal of International Money and Finance, 15, 485-96.

Sander, H., \& Kleimeier, S. (2002). Asymmetric adjustment of commercial bank interest rates in the euro area: An empirical investigation into interest rate pass through. Kredit und Kapital, 35, 161-92. 
Van Leuvensteijn, M., J. A. Bikker, Adrian A. R. J. M. van Rixtel., \& C. K. Sorensen (2011). A new approach to measuring competition in the loan markets of the euro area. Applied Economics, 43, 3155-3167. doi. org/10.1080/00036840903493234

Van Leuvensteijn, M., C. K. Sorensen, J. A. Bikker, Adrian A. R. J. M., \& van Rixtel (2013), Impact of bank competition on the interest rate passthrough in the euro area. Applied Economics, 45, 1359-1380. doi.org/10. 1080/00036846.2011.617697

Van Leuvensteijn, M., Bing, X., \& Adrian van Rixtel (2013). Measuring bank competition in China: A comparison of new versus conventional approaches applied to loan markets. Monetary and Economic Department, BIS Working Papers No 422.

Weth, M. A. (2002). The pass-through from market interest rates to bank lending rates in Germany. Deutsche Bundesbank Discussion Paper No. 11/02. dx.doi.org/10.2139/ssrn.320112. 